\title{
Review of Workers Inquiry Network (2020). Struggle in a Pandemic: A Collection of Contributions on the COVID-19 Crisis
}

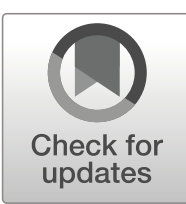

\section{London: Workers Inquiry Network. 128 pp. ISSN 2631-9284 (E-Book)}

\author{
Mark Smith ${ }^{1}$ \\ Published online: 14 July 2020 \\ (C) Springer Nature Switzerland AG 2020
}

Keywords Covid-19 $\cdot$ Pandemic $\cdot$ Struggle $\cdot$ Workers $\cdot$ Collective $\cdot$ Marx $\cdot$ Capitalism

\section{A Tool of Struggle}

The Struggle in a Pandemic collection from the Workers Inquiry Network (2020) considers the Covid-19 pandemic through the lens of the Marxist struggle for workers' rights. It is an enlightening and sometimes conflicted mixture from eight authorscollective writing that strives to make sense of the global crisis. At times it is polemical, ensconced in the history of conflict between capital and workers. At other times, it is close to heart-rending as it includes testaments from the oppressed. It suggests that a new post-capitalist future may be achieved through workers' self-organisation and provides a historical context for this. However, it also warns of how post-pandemic capitalism will ensure its recovery via increased oppression of the worker, regardless of the colour of their collar. The collection conflates the past, present and future. It suggests that activism may triumph whilst offering up a bleaker picture of the postpandemic world. At times it reveals an ethnographic intent to see the world through the eyes of the oppressed. At others it may turn towards a well-trodden rhetoric. Above all else, it provides a wealth of data from six countries (Belgium, Brazil, France, Italy, UK, USA) that provides a neatly balanced overview of how the pandemic may have impacted on the struggle for workers' rights and how self-organisation may yet provide the means for triumph against the pervasive control mechanisms of global capitalism.

In the introduction, the editors' suggestion that workers' inquiry 'can be developed as a tool of struggle' (Workers Inquiry Network 2020: 1) springs from Karl Marx's A Workers' Inquiry (1880). This recognises that 'statements of labor's grievances are the

Mark Smith

mark@marksmith.education

1 Solent University, Southampton, UK 
first act which socialist democracy must perform in order to prepare the way for social regeneration' (1). In comparison with Marx's collection of data from the French proletariat by the use of questionnaires, Invisíveis Goiânia (a small collective of activists) recorded the plight of Brazilian call centre operators. As Covid-19 cases increased, workers reported that colleagues 'are being fired and disappearing from their workstations' (70). This ethnographic tendency in the workers' inquiry used a variety of reporting mechanisms, including text messaging. Some of the data is highly emotive and at times distressing: "We are taking risks and this text is a cry for help' (77). Yet a note of hopeful praxis permeates this account. 'The courage of these workers was an inspiration to us and - we hope - may be an inspiration to others as well' (70).

Far more distanced is Sergio Bologna's fascinating historicisation of workers' selforganisation during Italy's 'Long Autumn' of the 1970s. This inclusion is a moment of brilliant editorship, as the chapter provides a useful background to the entirety of the book and especially Robert Ovetz's discussion of recent wildcat strikes in the USA. Bologna provides a detailed account of how Italian workers demanded and won the right to dignity and health in the workplace, echoing the demands of workers throughout the global pandemic over recent months. Most importantly, he recounts how workers' self-organisation provided a platform for an integrated social movement that drew upon the support of Italian society at large. The 'Long Autumn' workers' struggles in the 1970s provide a template of sorts for subsequent activism that moves beyond citations of Marx.

Personally, I was ignorant of much of what Bologna details and would like to thank the editors for its inclusion. I am surprised it is the last of the chapters, as it foregrounds and informs the development of workers' sense of identity that permeates the book. However, its presence in the text is impressive and revealing. The importance of the transfer of knowledge between workers is an important lesson to be learnt here, and I appreciate how this lesson is reciprocated by the publication of Struggle in a Pandemic. I was also struck by the importance for Italian workers of remaining healthy in the workplace. This attitude threads its way through the entire Covid-19 pandemic-related book.

\section{Protecting Workers' Health}

Who has not felt the need to protect themselves, their family and loved ones and their co-workers from exposure to the Covid-19 virus? Simon Downs created the illustration in Fig. 1 as a personal and evocative response to these feelings that are common to us all. Chapter 4 of Struggle in a Pandemic, jointly written by Into the Black Box and Officina Primo Maggio, highlights the vulnerability of the precariat, but also describes workers' protests for 'social-distancing measures in the storage places, sanitizations, plastic gloves, protective masks and other basic safety measures' (35). This aspect of the vulnerability of the precariat in terms of health (in opposition to the need of capitalism for continual production) is repeated from a French perspective by Plateforme d'enquêtes militantes in Chapter 2 and ACTA in Chapter 3. Plateforme relate demands 'to have production only to reproduce the species and save lives' (17) in the context of class war. ACTA spell this situation out bluntly: that it is those far down the social ladder who find themselves 'more exposed to the deadly threat of the virus' 
(26). It is worth noting that a French translation of Struggle in a Pandemic is now also available. $^{1}$

The relationship between workers' health concerns and the apparent insistence of governments to continue with production is repeated throughout Struggle in a Pandemic. In Chapter 1, AnkerMag introduce the authority's conception of 'national unity' versus workers' rights to health and dignity. In this case, that the Belgian government's priority was 'to secure the continuity of the accumulation process over the need to respond to the health, sanitary, and socio-economic crisis triggered by the pandemic' (6). With so much domestic concern about Covid-19 (worrying about highly vulnerable members of the family, the increasing local death rates, the number of ambulances on the street outside), the situation in Belgium did not register with me. Yet, AnkerMag cite the Johns Hopkins Coronavirus Resource Center (2020), who stated that Belgium had the highest Covid-19 death rate in the world proportional to its population. According to AnkerMag, this death rate was a direct outcome of delayed adoption of preventive measures - 'the result of negotiations between the government and the Federation of Belgian Entrepreneurs (FEB)' (5).

Checking the Johns Hopkins (2020) site today, I note that the UK now occupies this unwelcome top spot. Chapter 5 in the 'Notes from Below' (Workers Inquiry Network 2020: 43) repeats the accusation that our governments have not prioritised the health of its citizens, dictating that the UK government 'must be held accountable for tens of thousands of deaths'. 'Notes from Below' also introduce another concept that permeates this book: that the formerly disregarded service workers (from nursing to logistics) have been thrust to the fore in the mind of society. Again, this conception is laid out in detail from the historical perspective of Bologna's report on Italian workers' struggles in the 1970s. But the UK-focused chapter also reveals the hypocrisy of this novel depiction of these workers (many of whom are migrants) as 'heroes'. Just a few months ago, these same workers were 'told they were no longer welcome in the UK' (45).

\section{Workers' Demands}

There are many interesting instances of oppression and manipulation of vulnerable workers within Struggle in a Pandemic, and if this can at times seem truly dreadful, it is worth noting the sense of opportunity contained within the eight chapters. The increased sense of worth that many 'essential' workers have found and that has been offered in response by society is not to be dismissed lightly. The demands (developed by AnkerMag) for workers' rights that are underlined by this book are laid out:

1. A 'quarantine' salary or income

2. Suspension of rents, mortgages and bills

3. Requisitioning of private equipment and infrastructure needed to respond to the emergency, particularly in the health sector

4. Stop of all non-essential production activities

5. Amnesty for detainees and immediate regularization of undocumented migrants (Workers Inquiry Network 2020: 4)

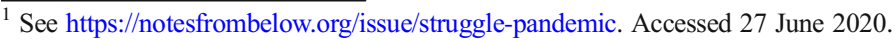




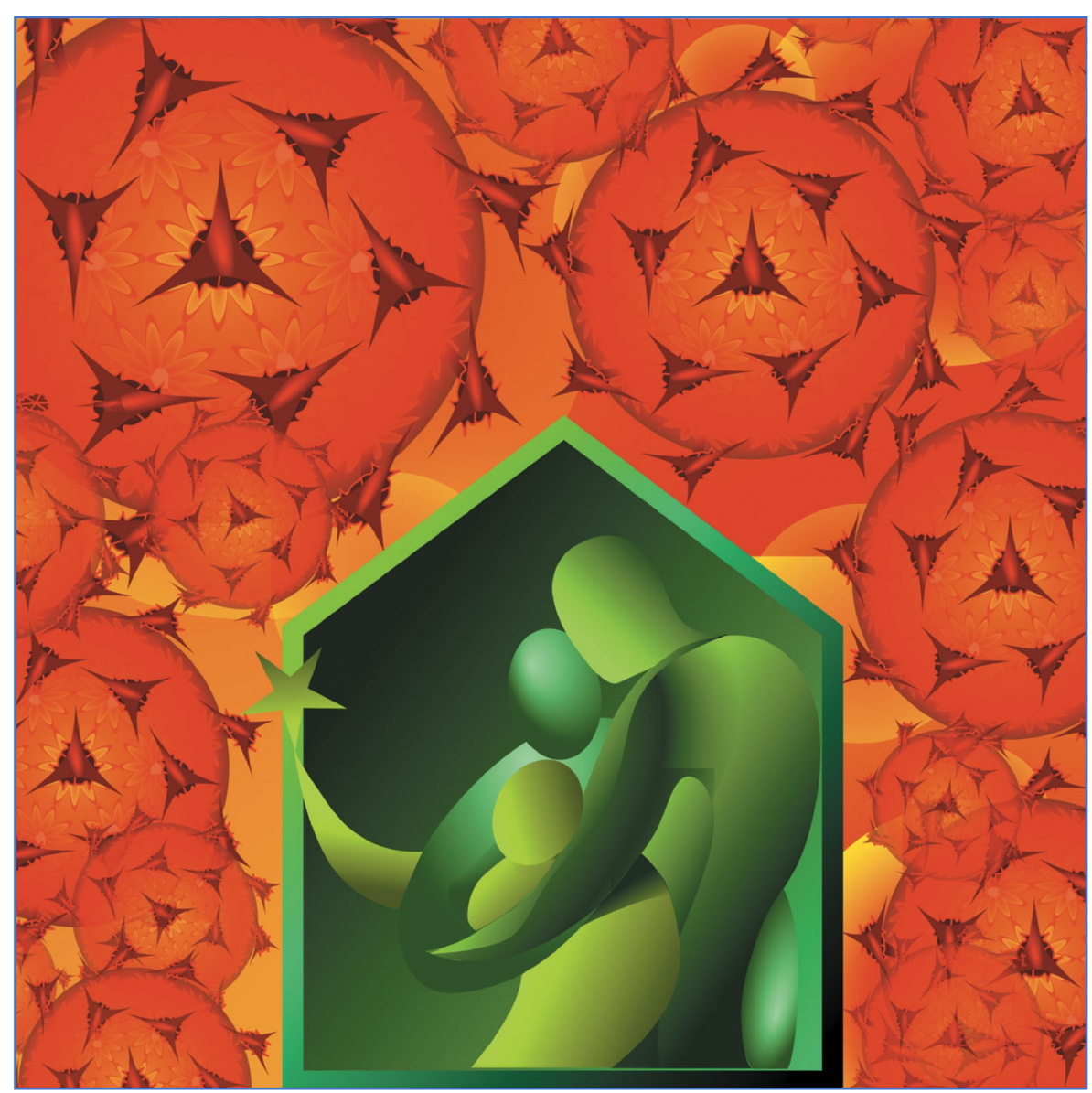

Fig. 1 C-19 (@Simon Downs 2020, reproduced with author's permission)

Whilst these demands constitute a reasonable response to the Covid-19 crisis, they are but one step in the formulation of a new egalitarian regard for workers by society at large and the development of governance that prioritises people over production.

There are many warnings in the book that capitalism will ultimately make use of the pandemic to forge its own future. A future in which the worker pays for the failure of global capitalism, not the businesses that depend on it. This is brilliantly summarised by Robert Ovetz in his chapter 'The Working Class Pandemic in the US':

There will continue to be state socialism for corporations and capitalism for workers. Unemployment will be used to bring down the hammer on what remains of the organized and unionized working class. Work will be reorganized to become even more precarious and the workplace even more despotically managed by data based surveillance. Skyrocketing deficits, borrowing, and corporate bailouts will become justification for further neoliberal austerity, privatization, disinvestment, and tax cuts for the rich and capital and regressive taxes on workers. Emergency executive powers will become normalized wielded with 
grotesque violence by authoritarians and corporate parties to recoup what is owed. (Workers Inquiry Network 2020: 54)

In conclusion, I found Struggle in a Pandemic (Workers Inquiry Network 2020) an interesting and informative read. It lays down challenges regarding self-organisation, transfer of knowledge and the upkeep of egalitarian principles. It highlights the disparity between the plight of the precariat and the needs of capitalism to continue production. Lastly, thanks to the inclusion of Bologna's piece, it asks us to learn lessons from the history of class struggle. But the book asks us to regard this history as alive and pertinent. That we make the choice to live 'in the furnace of history where memory is molten and can be bent into the contours of a dream' (Giroux and McLaren 1994: 218). This understanding of history as both malleable and forward-looking is reinforced when looking at today's news reports about the Covid-19 crisis. With the growing ease of lockdown in Europe, there is an increased risk of a resurgent virus. Will governments prioritise economic health over the health of their citizens? When President Bolsonaro (Phillips 2020) depicts the death of hundreds of thousands of human beings as so much collateral damage inflicted in defence of the Brazilian economy, is he a spokesperson for global capitalism? Struggle in a Pandemic: A Collection of Contributions on the COVID-19 Crisis (Workers Inquiry Network 2020) has been published as an immediate and vital response to the global crisis. If it had not - if it were published in 2021would it provide us with a different narrative? Bologna comments that Italy has a 'divided memory' (94) of workers' triumphs in the 1970s. Will the same be true of 2020 ?

\section{References}

Giroux, H., \& McLaren, P. (Eds.). (1994). Between borders: pedagogy and the politics of cultural studies. New York: Routledge.

Johns Hopkins Coronavirus Resource Center. (2020). Mortality analyses. Baltimore, MA: Johns Hopkins University https://coronavirus.jhu.edu/data/mortality. Accessed 26 June 2020.

Phillips, T. (2020). Brazil overtakes Italy as country with third highest coronavirus deaths. The Guardian, 5 June. https://www.theguardian.com/world/2020/jun/04/coronavirus-brazil-record-daily-death-tollmexico. Accessed 24 June 2020.

Workers Inquiry Network. (2020). Struggle in a pandemic: a collection of contributions on the COVID-19 crisis. London: Workers Inquiry Network. 